SCIREA Journal of Biology

http://www.scirea.org/journal/Biology

December 28, 2021

Volume 6, Issue 6, December 2021

https://doi.org/10.54647/biology18197

\title{
ANALYSIS OF ENCODING GENE FOR PALMITIC ACID CONTENT OF WINGED BEAN (Pshopocarpus tetragonolobus (L.) DC) SEEDS
}

\author{
Nurtjahjo Dwi Sasongko* and Adi Amurwanto \\ Faculty of Biology The University of Jenderal Soedirman, Purwokerto-Indonesia \\ *Correspondence(s) should be addresed to: nurtjahyo.sasongko@umsoed.ac.id
}

\begin{abstract}
Winged bean (Psophocarpus tetragonolobus (L.) (DC.) contains moderate to high fat in its seeds including palmitic acid (C18:0). Of those three sampling areas in Indonesia, the Sumateranese winged bean seeds contains $60 \%$; which is important raw source of various oleochemical industries. Palmitoyl $A C P$ is one among those enzyme involves in palmitic acid biosynthesis pathway from fatty acid synthase. Information about encoding genes of $A C P$ enzyme which involves in palmitic acid biosynthesis pathway, therefore, becomes a prerequisite and became the aim of this study. Current study designed three different specific primer for palmitic acids namely: A. palmitoyl-ACP, B. KAS III, and C. acc D. each of them has the following nucleotide sequences: A. forward primer (F) 5'-GTC GTG CAT CGG GGA AGA A -3' and reverse (R) 5'-TCG CTC CAT TTA GGC TGC AA-3'. B. KAS III (F) 5'TGC CAG ACA CCA TCA CAA ACT-3' and (R) 5'-TGA CGC CAG CGA TTA CAG C-3' and C. acc D (F) 5'-GGG CGT GAT GGA GTT TG-3' and (R) 5'-AGG TTG GCC TCG TTC TG-3' which were tested on three different genotypes the short pod winged beans, medium length pods and long pods ones on a PCR machine. The PCR resulted in amplicons
\end{abstract}


of $400 \mathrm{bp}$ from two genotypes only (short and medium length pods genotypes) but nit to long pod genotype. Interestingly that the fragments appeared at the same locus though they were characterized as different genotypes, this locus was then predicted as putative fragments of the palmitoyl ACP enzyme encoding gene in winged bean seed involves in the palmitic acid biosynthesis.

Keywords: palmitic acid, the palmitoyl $A C P$ enzyme, primers design, winged beans

\section{ENCODING GENE FOR PALMITIC ACID ....}

\section{Introduction}

Winged beans (Psophocarpus tetragonolobus (L.)(DC.) a tropical legume planted from low land to the high land up to 2,000 altitude; dried weather, temperature of $15-32^{\circ} \mathrm{C}$, humidity $50-90 \%$, soil $\mathrm{pH} 5.50-6.50$, rain falls of $2,500 \mathrm{~mm}$ per annum, and full day sun shine (Krisnawati, 2010). People consume its seeds which contains $17.5 \%$ fat in various fatty acids compound (Rismunandar, 1983) . Sasongko et al (2018) reported that the sumateranese winged bean seeds contain 40-60\% palmitic acid. Astawan (2009), grouping this fatty acids into unsaturated fatty acids (MUFA/monounsaturated fatty acids or PUFA/polyunsaturated fatty acids).

Palmitic acid is one among those saturated fatty acids characterized with 16 Carbon units and so fit to industrial purposes (Piazza and Foglia, 2001). This is the first product of plant's fatty acids which in turn would be elongated by palmitoyl-ACP elongase to form steraoyl-ACP (Cramer, 1990). Alternatively, the plant might synthesise this compound by esterifying acylACP thioesterase to co-enzym A to form (C16:0 co-A; Downey 1987).

Demands on palmitic acid for olechemical industries has increased annually and forces breeders to provide better quality of winged beans. Information about gene coding of palmitoyl-ACP enzyme therefore becomes a prerequisite step as a preliminary work to engineering high palmitic acid content winged beans. For doing so, a PCR technique might be applied as an initial phase.

A suitable primer is an important factor in PCR, however, in the mean times ther is no specific primer coding the palmitoyl-ACP enzyme in biosynthetic pathway of palmitic acid in 
winged beans available. The availability of this primer,therefore, becomes important to engineering high palmitic acid content in winged beans. Current study was then purposed to: 1. Designing a specific primer for coding the palmitoyl-ACP enyme gene which involves in the biosynthetic pathway of palmitic acid in winged beans.

2. Amplifying DNA fragments of coding gene of palmitoyl-KCP enzyme through PCR technique.

\section{Material and Methods}

The winged bean samples samples were grown in the green house belongs to the Faculty of Biology The University of Jenderal Soedirman -Purwokerto, Indonesia during the 2019 planting season. The genomic DNA was extracted from the third position of from the top leaf of each individual plant. Each of 5 gram leaf were brought to the genetics and molecular Biology laboratory of the University of Jenderal Soedirman in separate plastics clip and placed in a cool box. Following to this, the leaf then extracted using the gene-jet genomic plant DNA extraction kit (Thermo Science). The obtained genomic DNAs were then checked for their quality and quantity under a nanodrop spectrophotometer at the wavelengths of $\AA 230$, $\AA 260$, and $\AA 280$ then interpreted its absorbance at $\AA 260 / \AA 280$ and visualized using $1 \%$ (w/v) gel electrophorese, and checked in a gel-doc computer. The DNA concentrations were used along this study was calculated according to the following formula: $\AA 260 \times 50 \mathrm{ng} / \mu 1 \times \mathrm{F}$ (liqudifying factor).

Primer was designed by searching data of the DNA sequences encoding for palmitoyl-ACP enzyme in different plants and bacteria species (Brassicaceae, and bacteria data are not shown) registered in the gene bank. Data were then adopted to designing primer for gene coding the palmitoyl-ACP enzyme and so amplifying the DNA's fragments. Designing was done by applying a Primer3 program which was accessed through primer3.ut.ee, based on the conservative area of nucleotides data sequence after checking it on the MUSCLE program accesed through http://www.ebi.ac.uk.

Following to this, the newly-designed-primer was tested for its quality through IDT Oligo Analyzer program accessed from the http://sg.idtdna.com/calc/analyzer and tested for its specificity through blasting with the BLASTn program available in internet site of http://www.ncbi.nlm.nih.gov/blast. Nucleotides sequences of the forward and reverse primers, were substituted with other sequences as obvious in the IUPAC nucleotide code accesed in thehttp://www.bioinformatics.org.sms/iupac and so called as degerate-primer. The last form 
of primer was used in the PCR technique to amplify DNA fragments of encoding gene for palmitoyl-ACP enzyme.

Amplification of DNA fragments of encoding gene for palmitoyl-ACP enzyme was done by using PCR machine Primus 25 as suggested by Choudhary et al., (2008). Total volume for PCR was $19 \mu \mathrm{l}$, consists of $3 \mu \mathrm{l}$ sample DNA (80 ng/ $\mu \mathrm{l}$ ), 8,5 $\mu 1$ PCR super mix, $1 \mu 1$ forward

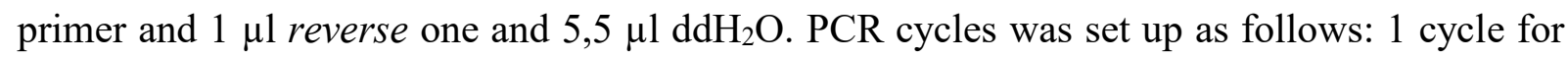
pre-denaturation of $94^{\circ} \mathrm{C}$ for 1 minute, and 35 cycles for reaction with $94^{\circ} \mathrm{C} 1$ minute predenaturation, 1 minute and 30 seconds for primer annealing $48.4^{\circ} \mathrm{C}, 2$ minutes for extension at $72^{\circ} \mathrm{C}$, and 1 more cycle for 10 minutes which set as post extension at $72^{\circ} \mathrm{C}$. The newly designed primers were having the following nucleotides: $A=$ palmitoyl ACP (F:5'-GTC GTG CAT CGG GGA AGA A-3'; and R: TCG CTC CAT TTA GGC TGC AA-3'); B= KAS III (F: 5'-TGC CAG ACA CCA TCA CAA ACT-3' and R: 5'-TGA CGC CAG CGA TTA CAG C3') and C= acc D (F:GGG CGT GAT GGA GTT TG-3' and R:AGG TTG GCC TCG TTC TG-3').

Observation was based on the following data of both DNA quality and quantity, quality of the designed-primers, primer's specificity, and observed DNA fragments. Quality of the obtained DNA extract was done in $1 \%(\mathrm{w} / \mathrm{v})$ electrophoresis gel while its concentration and quality was calculated using a nannodrop spectrophotometer at $\AA 230, \AA 260$, and $\AA 280$ wave length.

Test of newly designed-primer quality was done using an IDT Oligo Analyzer by counting the contents of guanine and cytocine, melting temperature, hairpins structures, self-dimer and hetero-dimer. The specificity of designed-was tested by blasting the new desgined-one to the NCBI data of the necleotide sequences of different plants available in the gene bank.

The DNA fragments were observed using the $U V$ transluminator at the $300 \mathrm{~nm}$ wavelength connected to a gel-doc computer.

\section{Results and discussions}

Current study succeeded in extracting genomic DNA of winged beans seeds (Fig. 1) though it was DNA contaminated by either RNA, phenol or protein (Tenriulo et al., 2001) appeared as smear or light band; a molecule of either destructed DNA or unidentified organic matter (Prayitno \& Nuryandani, 2011). Alternatively, it caused by the isolated-genomic DNA was not in a good condition. 


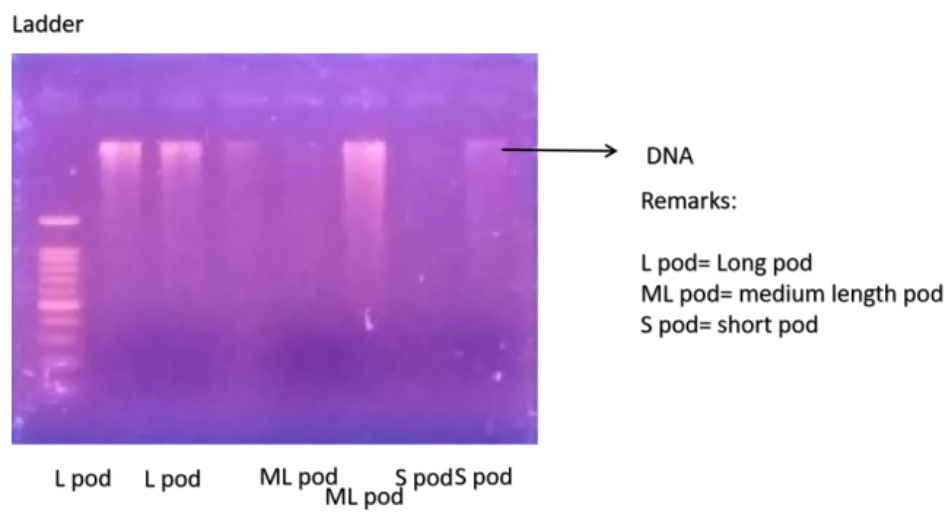

Figure1.Visualization of genomic DNA of winged beans isolated by gen-jet plant genomic extraction Kit thermo science

A good quality DNA, however, is characterized by its thickness, the thicker the band is therefore the better quality DNA. Utami et al., (2012) stated the thinner band's smear indicates the better extraction steps; addition of $3 \mu 1$ RNAse in thi study helped the purification of the extracted-genomic DNA prior to PCR.

Genomic DNA was obtained following the protocol of gene-jet plant extraction Kit and checked for its quantity and quality using a nannodrop spectrophotometer at $\AA 230, \AA 260$, and $\AA 280 \mathrm{~nm}$ wave lengths. The highest conentration of $50 \mathrm{ng} / \mu 1$ was noted from. The extracted genomic DNA was highly contaminated due to the extraction steps did not run well. Can be notified if it has score between 1,7-1,9 at the ratio of $\AA 260 / \AA 280$ (Majumder et al., 2011).

Table 1. Quality and quantity of genomic DNA of winged beans

\begin{tabular}{|l|l|l|l|}
\hline No & Samples & A260/280 $\mathrm{nm}$ & $\begin{array}{l}\text { Conentrations } \\
(\mathrm{ng} / \mu \mathrm{l})\end{array}$ \\
\hline 1 & Short pod 1 & 1.783 & 20.5 \\
\hline 2 & Short pod 2 & 1.750 & 24.5 \\
\hline 3 & $\begin{array}{l}\text { Medium } \\
\text { length 1 }\end{array}$ & 1.763 & 26.0 \\
\hline 4 & $\begin{array}{l}\text { Medium } \\
\text { length 2 }\end{array}$ & 1.695 & 50.0 \\
\hline 5 & Long pod 1 & 1.861 & 33.5 \\
\hline 6 & Long pod 2 & 1.839 & 28.5 \\
\hline
\end{tabular}

DNA concentration and purity can be affected by several factors like: process of homogenization with buffer, dissociation of the tissues, and DNA's precipitation (Sari et al.,2014). However, the older the leaf-samples the lower DNA quantity would be (Prayitno \& Nuryandani, 2011). The perfect stage of leave's development migth then important in extracting DNA. 
The success of PCR technique depends on several factors namely availability of primer to amplify DNA fragment, a significant compound in maximizing specificity and efficiency of PCR reaction (Sasmito et al., 2014).

Current study applied specific primer which were designed based on sequences of several nucleotides from different organisms plants and bacteria (data were not published) and crossed-checked with the MUSCLE program which were used as the main data to design the primer (Hughes et al., 2000), a designed primer might be applied to the DNA fragment only after being blasted.'Aziz (2010) reported if the more gene sequences and fit to the blasting program they might result in a shorter conserved area which affect primer's specificity in amplifying the target area. Following to this, a Primer 3 program was being used as also used in many aplications (Rozen \& Skaletsky, 2000) for setting the nucleotides sequence which resulted a nucleotides sequence of Acetyl-CoA carboxylase called A= palmitoyl ACP (F:5'-GTC GTG CAT CGG GGA AGA A-3'; and R: TCG CTC CAT TTA GGC TGC AA3'); B= KAS III (F: 5'-TGC CAG ACA CCA TCA CAA ACT-3' and R: 5'-TGA CGC CAG CGA TTA CAG C-3') and C= acc D (F:GGG CGT GAT GGA GTT TG-3' and R:AGG TTG GCC TCG TTC TG-3').

The newly designed primers have varied numbers of length from 17 to 21 nitrogen bases on their $\mathrm{F}$ and $\mathrm{R}$ primer. The newly designed primers might be grouped as good primers, since one of of the characteristic of a good primer suppossed to have 18-30 nitrogen bases which based on random combination of a sequence of particular genome (Sasmito et al., 2014).

Handoyo \& Rudiretna (2001), primer that has lesser than 18 /nitrogen bases will be less in its specificity but over 30 nitrogen bases not even increase specicifity. The newly designed primers were then stated as good ones since they have 17-19 Nitrogen bases.

The designed-primers have melting points between 57 and $64^{\circ} \mathrm{C}$ a situation where about 48 $59 \%$ of double bonds DNA would be split at the expected points. Handoyo and Rudiretna, (2001) stated the correct melting point plays a siginificant role in annealing of DNA fragments to the templates. If a primer is set at too high melting temperature it might cause low PCR product, in contrast, if melting point is set at too low temperature will produce non specific PCR products due to many mismatch bases (Borah, 2011).

Current primers also characterized with different GC content of $48-59 \%$ for forward and reverse primers. These contents are in between the ideal content as stated by Borah (2011) who stated the GC content of a primer varies between $40-60 \%$. A too low GC content may 
affect the competitiveness of the primer to anneal on the targetted gene area leads to lowering the PCR efficiency (Handoyo \& Rudiretna, 2001).

The designed-primers were also subjected to be tested for their quality and specificity, which were checked by an IDT Oligo Analyzer program while the second character was blasted for their nucleotide sequences in a BLASTn program. An IDT Oligo Analyzer analysis was purposed to get some informations related with secondary structures of the primer like hairpins, self-dimerand hetero-dimer which might beappeared on a particular designed-primer. This program gives some predictions on biophysics oligonucleotides and the sequence performance (Owczarzy, et al., 2008).

Hairpins are common type of secondary structure in RNA molecules and formed due to interaction between intramolecules of primer. Their present of these structure would therefore affect total number of primer along the amplification period, 'Azis (2010) stated that secondary structure like haripins sturctures would affect the annealing process of primer on the template leads to poor vision of PCR result.

In order to know the nucleotides available in the gene bank the current primer's specificity was tested by BLASTn program (Owczarzy et al., 2008) who reported the BLASTn program in checking a particular site for annealing of the primer's sequence and a particular sequence within the organism's genome. The BLASTn program, therefore, is normally used to check the specificity of designed-primer in order to know the fittest of the primer to the targetted DNA (Ye et al., 2012).

Based on its specificity analysis, both primers forward and reverse, have quite high similarity with the query coverage of $100 \%$ and low E-value (expectation value), but having similarity level of $80-100 \%$ (data were not published). Query coverage is a frequency of nucleotide bases which similar to the sequence of reference-gene in the gene bank (Haristianita, Saptasari, \& Listyorini, 2013). The query coverage of equal or larger than $25 \%$ means the nucleotide sequence is part of the target sequence as in the gene bank (Koonin \& Galperin, 2003).

The low E-value shows the specificity of designed primer to the BLASTn program has highly confident.E-valueof close to 0 (zero) shows a very high confident, cotrastingly the E-value of almost 1 shows low in confidence. Meanwhile the sequence similarity with the score between (80-100\%) shows the checked sequence of newly designed-primer have high similarity to those of available in gene bank. The higher the similarity score shows the primer might anneal on the target area specifically ('Aziz, 2010). 
Following to test for its quality and so its specificity, the newly designed-primers were then derived to its degenerate form. Kwok et al., (1994) in Wei et al., (2003) stated the degenerated-primer is a primer where one or more nucleotides can be filled by several nitrogen bases. In order to get their conserved area, the degenerate primers were blasted with data of early nucleotide sequences. Some nucleotide bases of either primer's forward or reverse which does not fit to the nucleotide sequenses then replaced with other nucleotides' bases as stated in the IUPAC mucleotide code. Current study noted thenucleotide sequences of degenerate forward primer was as follows:A= palmitoyl ACP (F:5'-GTC GTG CAT CGG GGA AGA A-3'; and R: TCG CTC CAT TTA GGC TGC AA-3'); B= KAS III (F: 5'-TGC CAG ACA CCA TCA CAA ACT-3' and R: 5'-TGA CGC CAG CGA TTA CAG C-3') and $\mathrm{C}=\operatorname{acc}$ D (F:GGG CGT GAT GGA GTT TG-3' and R:AGG TTG GCC TCG TTC TG-3').

Newly degenerated primers were then used to amplify palmitoyl-ACP enzyme encoding gene for palmitic acid through PCR. Visualization of PCR product using agarose gel of $1.5 \%(\mathrm{w} / \mathrm{v})$. The results are as folows: two primers (palmitoyl ACP and KAS III) produced a single band on $400 \mathrm{bp}$ for both individuals on short and medium genotypes. However, the KAS III and acc D primers produced a sinle band on short and medium genotypes located at the same length with those of produced by palmitoyl and KAS III primers (400 bp). The DNA of long pod winged bean genotype however, did not fi a the This situation indicating that gene for palmitic acid presents on short and medium long pod genotypes only i.e.: at about $400 \mathrm{bp}$ length fragments (Figure 2).

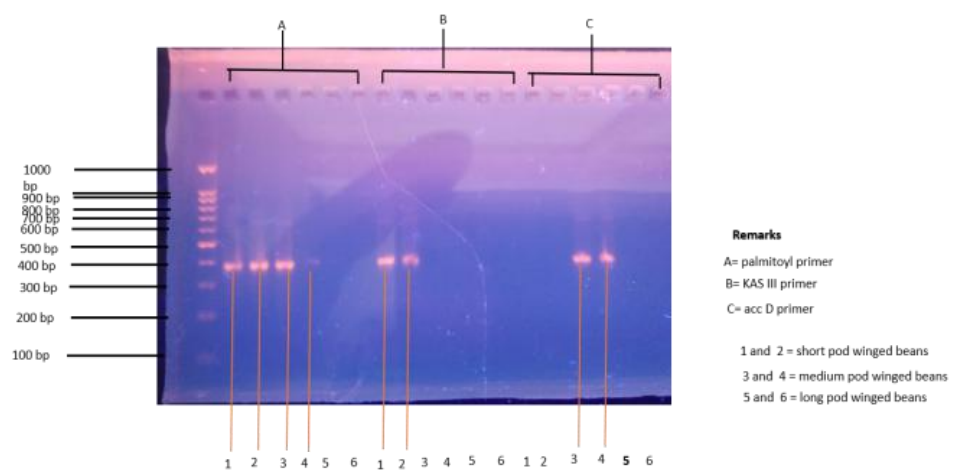

Figure2. Visualization of PCR product of 3 genotypes Winged bean (short, medium and long pods) DNA amplified by newly degenerate primers (palmitoyl ACP, KAS III an acc D)

Data of the current study unfortunately show a sligt discrepancy to that of reported by Wang et al., (2004) and Hutcheon et al., (2010), who reported encoding gene for the palmitoyl enzyme of Brassica napus 'maplus' and Crambe abysinnica 'galactica' were at the size of $540 \mathrm{bp}$, but $403 \mathrm{bp}$ noted from A. thaliana and Camelina sativa. The discrepancy noted in this 
study was might due to different samples were used, where current study used quite different from the subject of previous studies. Furthermore, current data were also different from data of Mietkiewska et al., (2004), who reported the size of DNA band encoding gene for KCS enzyme of the Nasturtium (Tropaeolum majus) at $650 \mathrm{bp}$. The explanation for this discrepancy might due to the different template was used in these two studies, current study used genomic DNA as its template in contrast with cDNA which was used before. Genomic DNA of a particular organisms has still an intergenic area (intron), whereas, the cDNA does not have any intron. The cDNA therefore, has only coding area to produce functional protein. Furthwermore, Nickel et al., (1991) reported that palmitic acid component in soy bean seeds was controlled by allele in three different loci. But, Sasongko et al., (2019) reported that the KCS enzyme which encoding for erucic acid content was close to the current study where the fragment was ampified by newly designed primer at about $480 \mathrm{bp}$. Indicating that the predicted gene for erucic acid was also at about $480 \mathrm{bp}$.

The present of DNA bands on different genotypes of sizes winged beans on the same distance could then be interpreted as DNA fragments of encoding gene for palmitoyl-ACP enzyme. If those DNA bands were fragment of encoding gene for the palmitoyl-ACP enzyme were amplified clearly, while the locus (ci) contains one single gene for biosynthetic of palmitic acid. Liu et al., (2016) reported that enhancing palmitic acid on cotton seed might be done through improvement of $g h$ KAS II enzymeto catalyse palmitoyl ACP. Both loci were known to affect production of palmitic acid in various plants (Fourmann et al., 1998; Roscoe et al., 2001; Yan et al., 2015; Sanyal et al., 2015).

Alternatively the presence of the DNA band was fragment of encoding gene for the palmitoylACP enzyme was due to the possibility of the newly designed degenerated primers, sticked on the intron (a non coding nucleotide sequence) of the genomic DNA of winged beans which still have many introns but numbers and size are still unclear. Along the PCR processes, these introns will be amplified together with the DNA fragments and produce non-specific products.These introns are located in either one locus or more loci. Gusmiaty et al., (2012) stated if the difference in DNA band sizes obtained in this study was merely due to many annealing areas inside the organism genome.

Data of nucleotide sequence which close to the winged beans was noted from two species, Glycine max and Medicago truncatula, the newly designed-primers were then knowing and complementing to the DNA sequences of the positive control rather than the research's object (winged beans). 
Numbers of DNA fragments amplified from short and medium genotypes of winged bean were probably due to there are not many spreaded-sites for primer to anneal in the DNA template. Alternatively, it might due to the amplification process was not appear on the long pod genotype (Weeden et al., 1974 in Poerba \& Martanti, 2008).

Meanwhile, the differences on winged-bean DNA's intensity was mainly due to primers inability to fully and strongly anneal on the target's genes fragment. Tingey et al., (1994) in Poerba \& Martanti, (2008) stated annealing process of a primer is affected by its ability in detecting the sequence of its DNA complementer. Furthermore, Grattapaglia et al., (1992) in Yuniastuti et al., (2010), stated the differences in intensity might probably due to primers competition to anneal on the DNA template, therefore some nucleotides might anneal in a large number of fragments others anneal on few numbers only. Moreover, Weeden et al., (1992) in Poerba \& Martanti (2008) exlpained if the DNA's intensity might resulted from the purity of the DNA itself. The contaminated DNA's either from polyshaccaraides or phenolic compounds and too little concentration might affect the DNA intensity.

\section{Conclusions}

Current study might conclude:

1. The newly designed primers have the

following sequences: A= palmitoyl ACP (F:5'-GTC GTG CAT CGG GGA AGA A-3'; and R: TCG CTC CAT TTA GGC TGC AA-3'); B= KAS III (F: 5'-TGC CAG ACA CCA TCA CAA ACT-3' and R: 5'-TGA CGC CAG CGA TTA CAG C-3') and C= acc D (F:GGG CGT GAT GGA GTT TG-3' and R:AGG TTG GCC TCG TTC TG-3’).

2. PCR amplification resulted in two DNA

bands at $400 \mathrm{bp}$ noted from short and medium pod winged bean genotypes and concluded as encoding gene for $\beta$-ketoacyl-CoA synthase enzyme which play a role in biosynthethic of erucic acid in winged beans.

\section{Acknowledgment}

The authors would like to thank you to The Rector of Jenderal University of Indonesia for funding the current reseach under the scheme of BLU-Unsoed No Kept 216/UN23.14/PN01.00/2019 dated of May 23 ${ }^{\text {th }}, 2019$. we also express our gratitude to Ir. Alice Yuniati, PhD, and Dr. Agus Herry Susanto, MS for their contributions for correcting 


\section{References}

[1] Astawan, M., 2009. Sehat dengan Hidangan Kacang dan Biji-Bijian. 1st ed. Jakarta: Penebar Swadaya.

[2] 'Aziz, S., 2010. Isolasi Fragmen Gen Penyandi Endoxilanase Streptomyces costaricanus 451-3 Melalui Pendekatan PCR. Tesis. Bogor. Institut Pertanian Bogor.

[3] Borah, P., 2011. Primer Designing for PCR.Science Vision, 11(3): 134-136.

[4] Choudhary, K., Mathur, N., Choudhary, O.P. \& Pillai, U., 2008. Protocol for Isolation of Genomic DNA from Dry and Fresh Leaves if Vigna Species Suitable for Rapd and Restriction Digestion. Advances in Biological Research, 2(5-6): 83-89.

[5] Doyle, J.J. \& Doyle, J.L., 1990.Isolation of Plant DNA from Fresh Tissue.Focus, 12(1): 13-15.

[6] Ferniah, R.S. \& Pujiyanto, S., 2013. Optimalisation on Isolation of Hot chilli DNA (Capsicum annuum L.) Based on different Quantity and Quality of Leaves and Grinding Technique.BIOMA, 156(1): 14-19.

[7] Fourmann, M., Barret, P., Renard, M., Pelletier, G., Delourme, R. \& Brunel, D., 1998. The Two Genes Homologous to Arabidopsis FAE1 co-segregate with the Two Loci Governing Erucic Acid Content in Brassica napus. Theory Applications Genetics, 96: $852-858$

[8] Gusmiaty, R.M. \& Pongtuluran, I., 2012. Selecting Primers for analysis of Genetic diversity of Bitti (Vitex coffassus).Jurnal Agrobiogen, 8(1): 25-29.

[9] Handoyo, D. \& Rudiretna, A., 2001. General Principles of Polymerase Chain Reaction (PCR).Unitas, 9(1): 17-29.

[10] Haristianita, M.D., Saptasari, M. \& Listyorini, D., 2013. Isolation of Encoding Gene for Flavonoid 3'5'Hidroksilase $(F 3$ '5' $H$ ) the Pecut Kuda (Stachytarpheta indica auct.Non (L.) Vahl) Herbs.Jurnal online Universitas Negeri Malang, 1(1): 1-5.

[11] Hughes, K.J.D., Fulton, C.E., McReynold, D. \& Lane, C.R., 2000.Development of New PCR Primers for Identification of Monilinia species. In OEPP/EPPO Bulletin Conference on Diagnostic Technique for Plant Pests, 30(3-4): 507-511, Wageningen, NL, September 2000. Wiley Online Library.

[12] Hutcheon, C., Ditt, R.F., Beilstein, M., Comai, L., Schroeder, J., Goldstein, E., Shewmaker, C.K., Nguyen, T., Rocher, J.D. \& Kiser, J., 2010.Polyploid Genome of 
Camelina sativa Revealed by Isolation of fatty acid synthesis Genes.BMC Plant Biology, 10(233): 1-15.

[13] Kadja, G.T.M., Rilyanti, M., Mukti, R.R., Marsih, I.N. \& Ismunandar., 2013. Strategic Synthesis of Zeolit: A Study of Soft and Hard Printing. Jurnal Matematika \& Sains, 18(3): 103-104.

[14] Koonin, E.V. \& Galperin, M.Y., 2003.Sequence-Evolution-Function: Computational Approaches in Comparatives Genomics. 2nd ed. Norwell, Massachusetss USA: Kluwer Academic Publishers.

[15] Krisnawati, A., 2010. Genetic Diversity and the Potential Development of Winged Beans (Psophocapus tetragonolobus (L.) DC)in Indonesia.fJurnal Litbang Pertanian, 29(3): 113-119.a.

[16] Liu Qing, M. Wu, B. Zhang, P. Shrestha, J. Petrie, A.G. Green, S.P. Singh. 2016. Genetic enhancement of palmitic acid accumulation in cotton seed through RNA I downregulation of $g h$ KAS II encoding $\beta$-ketoacyl ACP synthase (KAS II)

[17] Majumder, D.A.N., Hassan, L., Rahim, M.A. \& Kabir, M.A., 2011.Development of an Efficient Protocol for Genomic DNA Extraction from Mango (Mangifera indica). Nusantara Bioscience, 3(3): 105-111.

[18] Mietkiewska, E., Giblin, E.M., Wang, S., Barton, D.L., Dirpaul, J., Brost, J.M., Katavic, V. \& Taylor, D.C., 2004. Seed-Specific Heterologous Expression of a Nasturtium FAE Gene in Arabidopsis Results in a Dramatic Increase in the Proportion of Erucic Acid.Plant Physiology, 136: 2665-2667.

[19] Nickel, A.D., J.R. Wilcox, \& J. F. Cavins. 1991. Genetic Relationship Between Loci Controlling Palmitic and Linolecic acids in Soy bean. Alliance of Crop, Soil, and Environmental Society.vol 31. No:5. pp: 1169-1171.

[20] Owczarzy, R., Tataurov, A.V., Wu, Y., Manthey, J.A., McQuisten, K.A., Almabrazi, H.G., Pedersen, K.F., Lin, Y., Garretson, J., McEntaggart, N.O., Sailor, C.A., Dawson, R.B. \& Peek, A.S., 2008. IDT SciTools: a Suite for Analysis and Design of Nucleic Acid Oligomers. Nucleic Acid Research, 36: 163-169.

[21] Poerba, Y.S. \& Martanti, D., 2008. Genetic Diversity based on an RAPD Markers: Polymorphic DNA of Amorphophallus muelleri Blumein Java.BIODIVERSITAS, 9(4): 245-249.

[22] Prayitno, E. \& Nuryandani, E., 2011. Optimatization of DNA Extraction of Physic Nut (Jatropha curcas) by Selecting the Appropriate Leaf. Nusantara Bioscience, 3(1): 1-6. 
[23] Rismunandar, 1983. Winged Beans Protein and Carbohydrate Source. Bandung: Sinar Baru.

[24] Roscoe, T.J., Lessire, R., Puyaubert, J., Renard, M. \& Delseny, M., 2001. Mutations in the fatty acid elongation 1 Gene are Associated with a Loss of-ketoacyl-CoA synthase Activity in Low Erucic Acid Rapeseed. Federation of European Biochemical Societies Letters, 492: 107-111.

[25] Rozen, S. \& Skaletsky, H., 2000.Primer3 on the WWW for General Users and for Biologist Programmers. In S. Misener \& S.A. Krawetz, eds. Methods in Molecular Biology, 132: 365-368, Bioinformatics Methods and Protocols. Totowa, NJ. Humana Press.

[26] Sanyal, A., Pinochet, X., Merrien, A., Laustriat, M., Decocq, G. \& Fine, F., 2015. Erucic Acid Rapeseed: 1. Prospect of Improvements. Oilseeds \& Fats Crops and Lipids Journal, 22(3): 1-10.

[27] Sari, S.K., Mazieda, M.N., Listyorini, D. \& Sulasmi, E.S., 2014. Optimation of DNA Isolation and Purification Technique of Hot Chilli (Capsicum frutescens cv. Green Cakra) Using Genomic DNA Mini Kit (Plant) Geneaid. In Seminar Nasional XI Pendidikan Biologi FKIP UNS. Solo, 2014.

[28] Sasongko, N.D., S. A'ziz, \& Y. Sulistyono. 2019. Degenerated Primers for the KCS Enzyme Gene Encoding erucic Acid Content in Winged Bean Seeds. Proceeding of ICOMIRE. Indonesia. In Press.

[29] Sasmito, D.E.K., Rahadian, K. \& Muhimmah, I., 2014. Characteristics of Primers on Polymerase Chain Reaction (PCR) for DNA Sequencing: Mini Review. In Seminar Nasional Informatika Medis (SNIMed) V. Yogyakarta, 2014.

[30] Tenriulo, A., Suryati, E., Parenrengi, A. \& Rosmiati, 2001. Extraction of SeaWeeds Kappaphycus alvarezii DNA Using a Phenol Chloroform Method.Marina Chimica Acta, 2(2): 6-10.

[31] Utami, A., Meryalita, R., Prihatin, N.A., Ambarsari, L. \& Asri, P., 2012. Variation of DNA Isolation of (Curcuma xanthorrhiza Roxb.) Methods. In Prosiding Seminar Nasional Kimia Unesa 2012. Surabaya 2012.

[32] Wang,Y.P., Snowdon, R.J., Rudloff, E., Wehling, P., Friedt, W. \& Sonntag, K., 2004. Cytogenetic Characterization and fael Gene Variation in Progenies from Asymetric Somatic Hybrids between Brassica napus and Crambe abysinnica.Genome, 47: 724-731. 
[33] Wei, X., Kuhn, D.N. \& Narasimhan, G., 2003. Degenerate Primer Design via Clustering.In IEEE Computer Society Bioinformatics Conference.Miami, 2003.USDAARS, Subtropical Horticultural Research Station.

[34] Yan, G., Li, D., Cai, M., Gao, G., Chen, B., Xu, K., Li, J., Li, F., Wang, N., Qiao, J., Li, H., Zhang, T. \& Wu, X., 2015. Characterization of FAE1 in the Zero Acid Germplasm of Brassica rapaL. Breeding Science, 65(3): 257-264.

[35] Ye, J., Coulouris, G., Zaretskaya, I., Cutcutache, I., Rozen, S. \& Madden, T.L., 2012. Primer-BLAST: A Tool to Design Target-Specific Primers for Polymerase Chain Reaction. BioMed Central Bioinformatics, 13(134): 1-11.

[36] Yuniastuti, E., Supriyadi \& Ruwaida, I.P., 2010. Genetic Diversity Analysis of Durian Sukun (Durio zibethinus Murr.) Based on an RAPD Markers. In Seminar Nasional Pendidikan Biologi FPIK UNS. Solo, 2010. 